\title{
LIETUVOS BOKSININKŲ IR KARATE் KOVOTOJŲ SPORTINĖS VEIKLOS MOTYVAI
}

\author{
Vida Ivaškienė ${ }^{1}$, Virgilijus Vytautas Mačiulis ${ }^{1}$, Leonas Meidus ${ }^{2}$, Vidas Bružas ${ }^{1}$, Vladas Juknevičius ${ }^{3}$ \\ Lietuvos kūno kultūros akademija ${ }^{1}$, Kaunas, Vilniaus pedagoginis universitetas ${ }^{2}$, Vilnius, \\ Vytauto Didžiojo universitetas ${ }^{3}$, Kaunas, Lietuva
} Vida Ivaškienė. Docentè socialinių mokslų daktarè. Lietuvos kūno kultūros akademijos Sporto pedagogikos ir psichologijos katedros docentė.
Mokslinių tyrimų kryptis - įvairaus amžiaus žmonių fizinis pajėgumas ir nuostata į kūno kultūrą.

\section{SANTRAUKA}

Tirti savo auklètiniu sportinès ir varžybinès veiklos motyvus, šiuos motyvus skiepyti - svarbi trenerio darbo sritis. Lietuvoje boksininku ir karatè kovotoju sportinès veiklos motyvai iki šiol menkai tyrinèti.

Tyrimo tikslas - ištirti ir palyginti Lietuvos boksininku, karate kovotoju sportinès veiklos motyvus.

Tyrimo metodai: literatūros šaltiniu analizè, anketavimas, matematiné statistika.

Anketine apklausa atlikta 2004 metais per Lietuvos suaugusiuju bokso pirmenybes. Buvo tiriama 30 Lietuvos boksininku ir 32 karate kovotojai $(n=62)$. Anketineje apklausoje dalyvavo 29 didelio (14 boksininku ir 15 karate kovotoju) ir 33 mažo meistriškumo (16 boksininku ir 17 karaté kovotoju) sportininkai. Tiriamuju amžiaus vidurkis - 20,5 $\pm 2,3$ metu.

Tiriamiesiems buvo pateikta 56 klausimu standartizuota F. Herzberg anketa, aprobuota LKKA Sporto pedagogikos ir psichologijos katedros, norint nustatyti šiuos aštuonis veiklos motyvus: finansiní, pripažinimo ir dèkingumo, atsakomybès, santykiu su vadovu, karjeros, laimèjimu, darbo turinio, bendradarbiavimo.

Tyrimo rezultatai apdoroti matematinès statistikos metodais. Apskaičiuotos gautu rezultatu vidutinès reikšmès, vidutinis kvadratinis nuokrypis. Skirtumo patikimumas nustatytas pagal Stjudento t kriteriju. 95\% patikimumo lygmuo $(p<0,05)$ laikytas statistiškai patikimu.

Nustatyta, kad didelio meistriškumo Lietuvos boksininkams ir karatè kovotojams reikšmingiausi darbo turinio ir laiméjimu motyvai, mažo meistriškumo sportininkams — darbo turinio, bendradarbiavimo ir atsakomybès. Didelio meistriškumo boksininkams finansinis, pripažinimo ir dèkingumo, karjeros ir laimèjimu motyvai yra svarbiausi, palyginti su karaté kovotoju $(p<0,05)$. Mažo meistriškumo boksininkams finansinis motyvas svarbesnis nei tokio paties meistriškumo karatè kovotojams ( $p<0,05)$, bet mažiau svarbus nei didelio meistriškumo boksininkams $(p<0,001)$. Visiems respondentams nereikšmingiausias yra karjeros motyvas.

Raktažoď̌iai: sportinès veiklos motyvai, didelis ir mažas meistriškumas, boksas, karatè.

\section{IVADAS}

$\mathrm{M}$ otyvas - tai sąmoninga ar nesąmoninga veiksmo priežastis, kylanti dèl asmenybès ir objekto (situacijos), patenkinančios jos poreikius, interesus, vertybes ir tikslus, sąveikos (Sporto terminu žodynas, 2002).

Motyvacija - visuma motyvų, lemiančiu sportininko aktyvumą siekiant užsibrež̌to tikslo per pratybas ir varžybas (Sporto terminu žodynas, 2002). Sportinès veiklos motyvacija svarbi sportininko psichologinio rengimo dalis. Sportinę motyvaciją yra tyrę ivvairių šalių mokslininkai (Deci, Ryan,
1985; Csikzentmihalyi, Nakamura, 1989; Flood, Hellsted, 1991; Худадов, 1997; Wang, Biddle, 2001), bet sportinès veiklos motyvacijos tyrimuc aktualumą lemia besitęsiančios motyvacijos teorijų ir metodikos paieška, motyvų sportuoti nustatymas (Malinauskas, 1998).

F. Herzberg (1996) pabrèžè, kad asmenybès motyvaciją veikia dviejų veiksniu grupès - palaikomuju ir skatinamujų: palaikomieji veiksniai treniruotès sąlygos, materialus atlygis, sportininko ir trenerio santykiai, jų santykiai su komandos 
draugais; skatinamieji veiksniai — tai galimybe tobulèti, laimèjimai, pripažinimas. Būtinos abi motyvacijos veiksniu grupès.

Sportinès veiklos motyvai susiję su varžybinès veiklos sėkmingumu (Бондарчук, Потапов, 2006). Mokslinė problema ta, kad stinga žinių, ar dvikovos šakų atstovų sportinès veiklos motyvai yra panašūs, nes Lietuvoje yra tyrinèti tik didelio meistriškumo boksininkų, graikų-romėnų imtynininkų sportinès veiklos motyvai (Malinauskas, 2003). Buvo tiriami boksininkai ir karate kovotojai, nes iš dvikovos šaku jie išsiskiria tuo, kad sportinè kova vyksta tik stovint ir naudojama tik smūgio technika.

Tyrimo objektas - Lietuvos boksininku ir karatė kovotojų sportinès veiklos motyvai.

Tyrimo tikslas - ištirti ir palyginti Lietuvos boksininkų ir karatè kovotojų sportinès veiklos motyvus.

\section{Tyrimo uždaviniai:}

1. Ištirti Lietuvos didelio meistriškumo boksininku ir karate kovotojų sportinès veiklos motyvus.

2. Ištirti Lietuvos mažo meistriškumo boksininkų ir karate kovotojų sportinės veiklos motyvus.

3. Palyginti didelio ir mažo meistriškumo tiriamųjų sportinès veiklos motyvus.

Hipotezè - olimpinès šakos (bokso) sportininkams finansinis motyvas yra svarbesnis nei neolimpinès šakos (karatè) sportininkams.

\section{TYRIMO METODIKA IR ORGANIZAVIMAS}

Tyrimo metodai: literatūros šaltinių analizè, anketavimas, matematine statistika.

Anketavimas buvo vykdomas 2004 metais per Lietuvos suaugusiujų bokso pirmenybes. Tiriamaja imti sudare keturių svorio kategoriju (nuo 57 iki $75 \mathrm{~kg}$ ) sportininkai, nes kitų svorio kategorijų dalyvių būna mažai. Didelio meistriškumo sportininkams buvo priskiriami pirmieji keturi laimètojai, o mažo meistriškumo - paskutines keturias vietas užèmusieji. Tirta 30 boksininkų ir 32 karatè kovotojai $(\mathrm{n}=62)$. Anketineje apklausoje dalyvavo 29 didelio (14 boksininkų ir 15 karatė kovotojų) ir 33 mažo meistriškumo (16 boksininkų ir 17 karatè kovotoju) sportininkai. Buvo planuota ištirti po 16 kiekvienos grupès tiriamujų, tačiau didelio meistriškumo sportininkų grupèse trys anketos buvo nebaigtos pildyti, o mažo meistriškumo grupejje papildomai itrauktas vienas karatė kovotojas, atsižvelgiant i varžybu vyriausiojo teisejjo rekomendacijas. Tiriamuju amžiaus vidurkis $-20,5 \pm 2,3$ metu.

Tiriamiesiems buvo pateikta 56 klausimų standartizuota F. Herzberg anketa, aprobuota LKKA Sporto pedagogikos ir psichologijos katedros, norint nustatyti šiuos aštuonis veiklos motyvus: finansini, pripažinimo ir dèkingumo, atsakomybès, santykiu su vadovu, karjeros, laimejjimų, darbo turinio, bendradarbiavimo. Aukščiausias kiekvieno motyvo ivertis - 28 balai.

Tyrimo rezultatai apdoroti matematinès statistikos metodais. Buvo apskaičiuojamos gautu rezultatų vidutinès reikšmès, vidutinis kvadratinis nuokrypis. Skirtumo patikimumas nustatytas pagal Stjudento $t$ kriteriju. 95\% patikimumo lygmuo $(\mathrm{p}<0,05)$ laikytas statistiškai patikimu.

\section{REZULTATAI}

Lietuvos didelio meistriškumo boksininkams sportineje veikloje svarbiausias finansinis motyvas $(25,6 \pm 1,02$ balo), gana reikšmingi darbo turinio

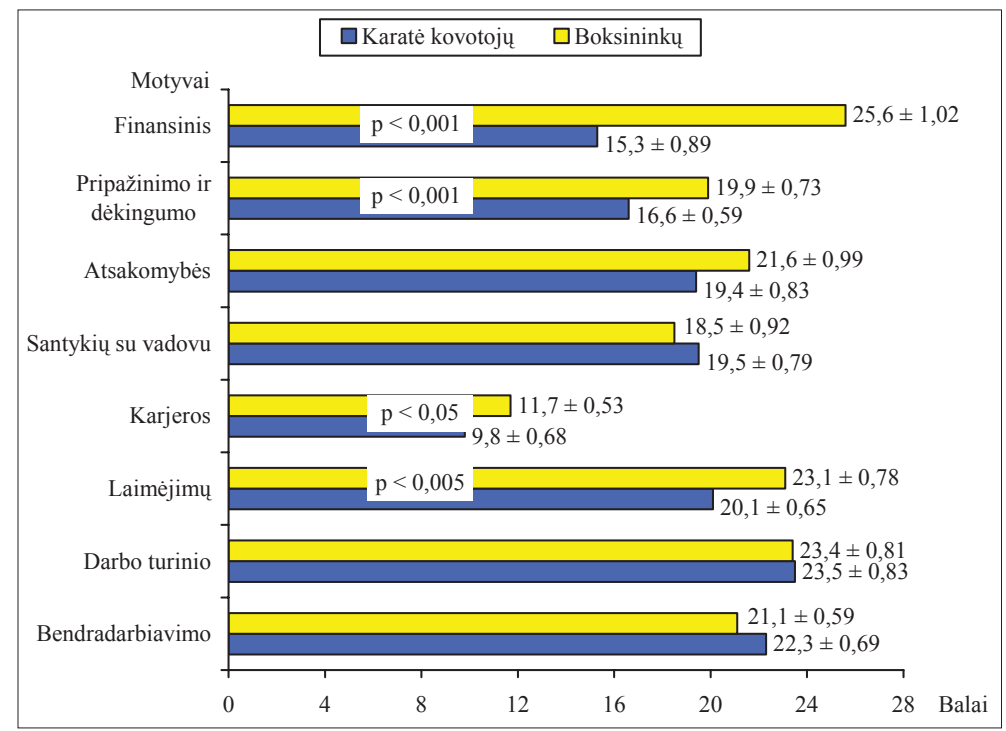

1 pav. Didelio meistriškumo boksininkų ir karatė kovotojų sportinès veiklos motyvai (balai, $\overline{\mathbf{X}} \pm \mathbf{S} \overline{\mathbf{x}}$ ) 
2 pav. Mažo meistriškumo boksininkų ir karatė kovotojų sportinės veiklos motyvai (balai, $\overline{\mathbf{x}} \pm \mathbf{S} \overline{\mathbf{x}}$ )

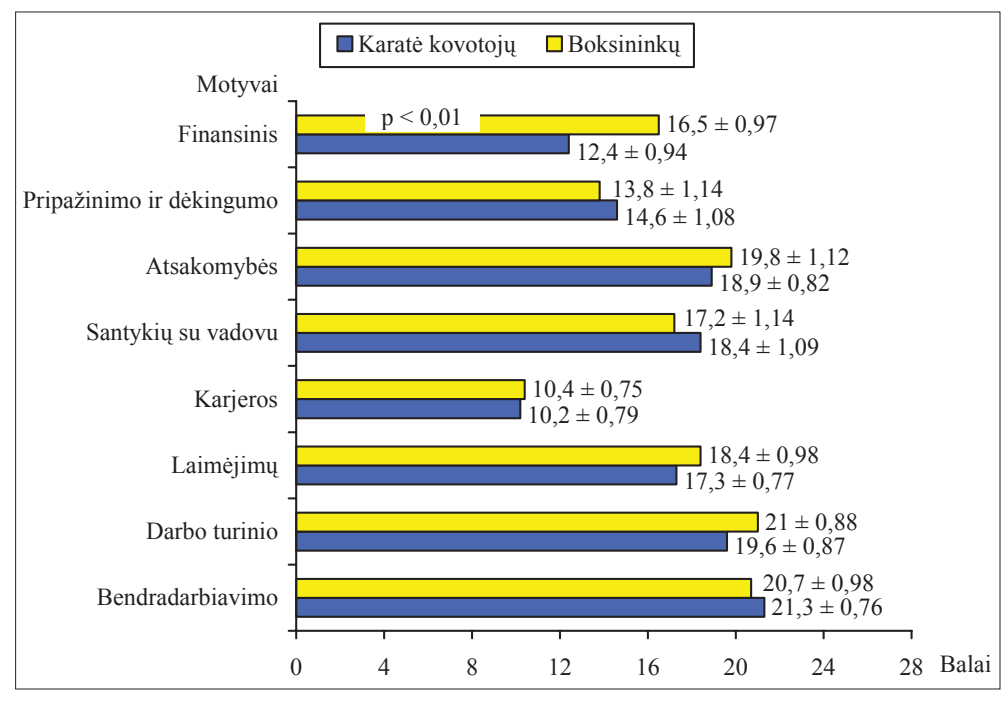

3 pav. Tiriamųjų finansinio motyvo poreiškis $(\overline{\mathbf{x}} \pm \mathbf{S} \overline{\mathbf{x}})$
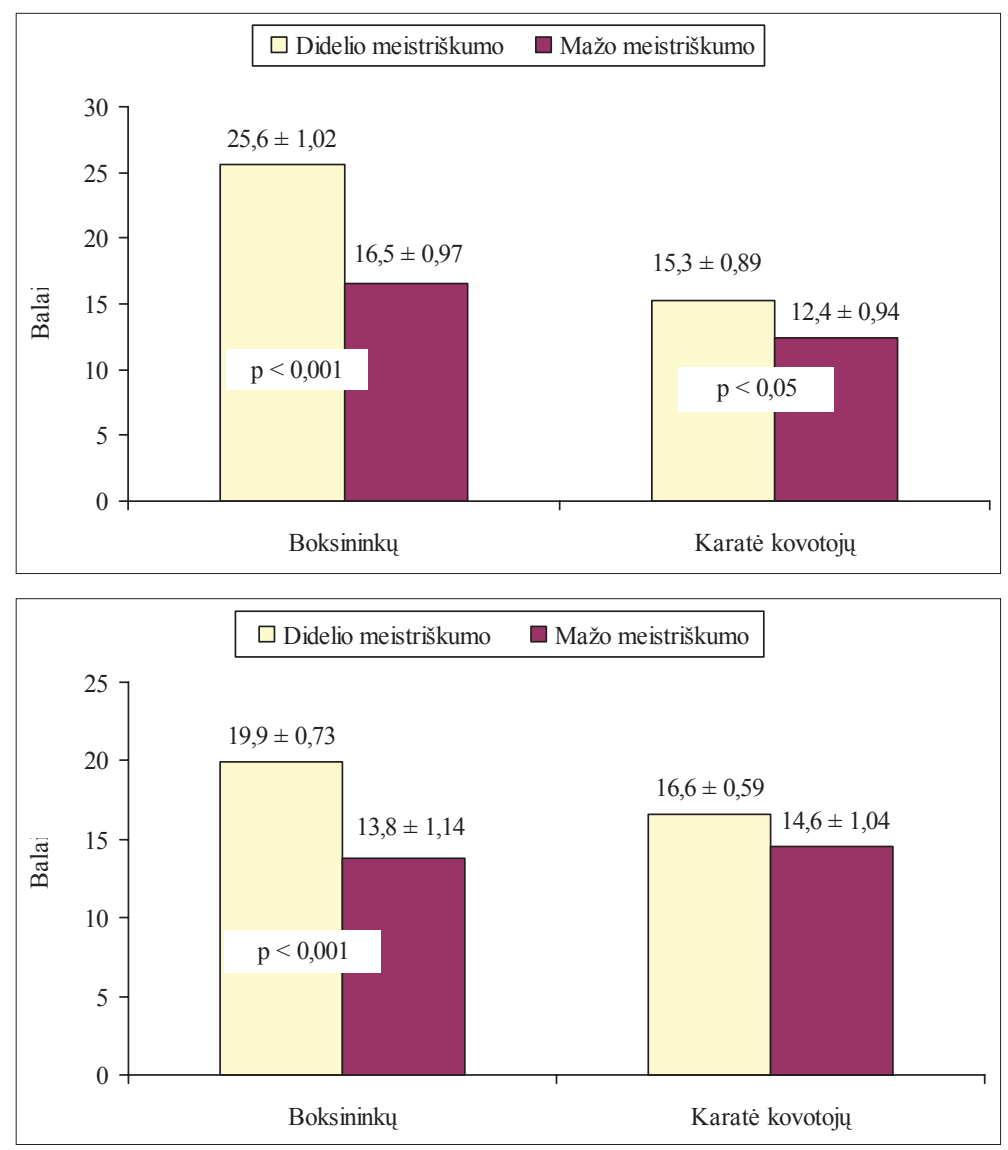

4 pav. Tiriamųjų pripažinimo ir dẻkingumo motyvo poreiškis $(\overline{\mathbf{x}} \pm \mathbf{S} \overline{\mathbf{x}})$
$(23,4 \pm 0,81$ balo $)$ ir laimejjimu $(23,1 \pm 0,78$ balo $)$ motyvai (1 pav.). Didelio meistriškumo karate kovotojams reikšmingiausias darbo turinio motyvas $(23,5 \pm 0,83$ balo), gana svarbūs - bendradarbiavimo $(22,3 \pm 0,69$ balo $)$ ir laimejjimu (20,1 $\pm 0,65$ balo) motyvai ( 1 pav.).

Mažo meistriškumo boksininkams sportinejje veikloje svarbiausi darbo turinio $(21,0 \pm 0,88$ balo), bendradarbiavimo $(20,7 \pm 0,98$ balo $)$ ir atsakomybès $(19,8 \pm 1,12$ balo) motyvai, karate kovotojams - bendradarbiavimo $(21,3 \pm 0,76$ balo $)$, darbo turinio $(19,6 \pm 0,88$ balo $)$ ir atsakomybès $(18,9 \pm 0,82$ balo) (2 pav.).

Matyti, kad skirtingo meistriškumo boksininkams labai svarbūs darbo turinio motyvai, o skirtingo meistriškumo karatė kovotojams — darbo turinio ir bendradarbiavimo.

Didelio meistriškumo sportininkams gana svarbus laimėjimų, mažo meistriškumo - atsakomybès motyvas.

Palyginti su kitais motyvais, visiems respondentams nereikšmingiausias karjeros motyvas $(\mathrm{p}<0,05)$. 

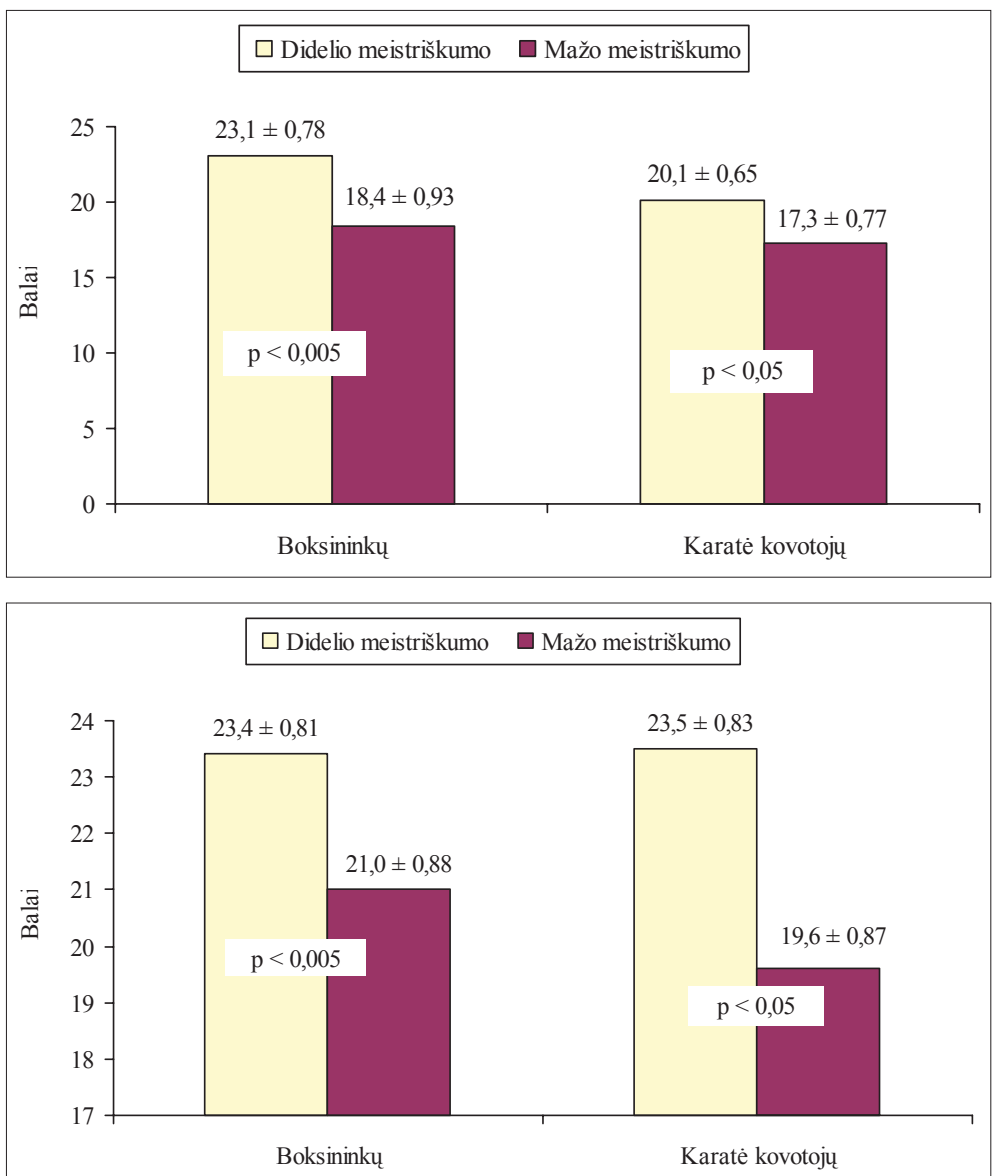

Lyginant didelio meistriškumo boksininkų ir karate kovotojų sportinès veiklos motyvus nustatyta, kad boksininkams finansinis, pripažinimo ir dèkingumo, karjeros ir laimejjimu motyvai svarbesni nei karatė kovotojams ( $\mathrm{p}<0,05-0,001)$ (1 pav.).

Lyginant mažo meistriškumo boksininku ir karatė kovotoju sportinès veiklos motyvus nustatyta, kad boksininkams finansinis motyvas svarbesnis nei karate kovotojams $(\mathrm{p}<0,01)$ (2 pav.).

Nagrinejjant finansinio motyvo poreiškius nustatyta, kad didelio meistriškumo sportininkams šis motyvas svarbesnis nei mažo meistriškumo sportininkams $(\mathrm{p}<0,05-0,001)(3$ pav.).

Išnagrinèjus tiriamujuc pripažinimo ir dèkingumo motyvo poreiškius nustatyta, kad didelio meistriškumo boksininkams jis yra svarbesnis nei mažo meistriškumo boksininkams $(p<0,001)$ (4 pav.).

Laimėjimu motyvas svarbesnis didelio meistriškumo sportininkams $(\mathrm{p}<0,05-0,005)$ (5 pav.).

Darbo turinio motyvo poreiškio tyrimai parodè, kad didelio meistriškumo respondentams jis svarbesnis (6 pav.).
5 pav. Tiriamųjų laimėjimų motyvo poreiškis

$(\overline{\mathbf{X}} \pm \mathbf{S} \overline{\mathbf{x}})$

6 pav. Tiriamujų darbo turinio motyvo poreiškis $(\overline{\mathbf{x}} \pm \mathbf{S} \overline{\mathbf{x}})$

\section{REZULTATUQ APTARIMAS}

Boksininkų ir karate kovotojų sportinès veiklos motyvų tyrimai parodè, kad didelio ir mažo meistriškumo boksininkams finansinis motyvas reikšmingesnis negu karatė kovotojams. Taigi hipotezè pasitvirtino.

Jeigu tarp mažo meistriškumo respondentu motyvų didesnio skirtumo nèra $(p>0,05)$, tai didelio meistriškumo boksininkams pripažinimo ir dèkingumo, karjeros, laimèjimų motyvai svarbesni negu to paties meistriškumo karate kovotojams $(\mathrm{p}<0,05)$. Taip yra galbūt dèl to, kad karatè — ne olimpinè sporto šaka.

Boksininku apklausos rezultatai patvirtina J. Kinjonen (1991) nuomonę, kad labai dažnai tarp pagrindinių sportavimo motyvų minimas ir materialios naudos siekis. Anot F. Herzberg motyvacijos teorijos, darbas turi būti modifikuojamas taip, kad asmuo turètų galimybę patirti sèkmę, pripažinima, atsakomybę ir tobulejjimą (Coffey et al., 1994). Šio tyrimo duomenys tokiai teorijai neprieštarauja.

Tiriamiesiems reikšmingas bendradarbiavimo motyvas rodo, kad sportininkų tarpusavio santykiai yra geri, vyrauja supratimas. Darbo turinio reikšmingumas atskleidžia įvairaus meistriškumo 
sportininkų domejjimąsi treniravimosi metodika, ivairiais jos būdais.

Nereikšmingiausias visiems tiriamiesiems karjeros motyvas atskleidžia boksininkų ir karatè kovotojų sportinès veiklos sąstingio grèsmę: negilios veteranų sporto tradicijos arba jų stoka, finansiniai sunkumai ir pan. Tačiau kartu tiriamieji suvokia ir tai, kad profesionalaus sportininko karjera yra palyginti trumpa.

Visiems tiriamiesiems svarbus atsakomybès motyvas. Tai rodo tiriamujų moralinę brandą ir sportiniu igūdžių taikymo įvairiomis aplinkybèmis galimus padarinius.

Nagrinejjant kitų dvikovos šakų atstovų sportinès veiklos motyvaciją buvo nustatyta, kad fechtuotojams svarbiausias laimejjimų motyvas (Čepelionienė, Ivaškienė, 2005). Siekimų motyvacija - tai motyvu visuma, nuteikianti sportininka siekti kovos, varžytis arba jos vengti. Tai pagrindinè varomoji jèga siekiant užsibrezžtų tikslų (Sporto terminu žodynas, 2002).

R. Malinausko (2003) tyrimo pagal kitokią motyvu tyrimo anketą duomenys parode, kad didelio meistriškumo boksininkus, graikų-romėnu imtynininkus, taip pat ju pamainą sportuoti labiausiai skatina motyvas būti fiziškai stipriam, sustiprinti sveikatą, rungtyniauti, tapti čempionu, rekordininku.

Dvikovos šakose siekiant rezultatų sportinès veiklos motyvai yra labai reikšmingi, todèl trene- ris turi gerai žinoti kiekvieno auklètinio sportavimo motyvus, juos kryptingai ugdyti (Худадов, 1997). Manoma, kad treneris, žinodamas ugdytinio sportinès veiklos motyvus, gali padèti sportininkui tapti ryžtingesniam, atkaklesniam igyvendinant savo siekius, ilgiau tęsti sportinę karjera.

\section{IŠVADOS}

1. Didelio meistriškumo Lietuvos boksininkams reikšmingiausi finansinis $(25,6 \pm 1,02$ balo $)$, darbo turinio $(23,4 \pm 0,81$ balo) ir laimejjimu (23,1 $\pm 0,78$ balo) motyvai, karate kovotojams - darbo turinio $(23,5 \pm 0,83$ balo), bendradarbiavimo $(22,3 \pm 0,69$ balo $)$ ir laimèjimu (20,1 $\pm 0,65$ balo).

2. Mažo meistriškumo sportininkams reikšmingiausi darbo turinio, bendradarbiavimo ir atsakomybès motyvai.

3. Didelio meistriškumo boksininkams finansinis, pripažinimo ir dékingumo, karjeros ir laimèjimų motyvai yra svarbiausi, palyginti su karate kovotojais.

4. Mažo meistriškumo boksininkams finansinis motyvas svarbesnis už tokio paties meistriškumo karatė kovotojų $(\mathrm{p}<0,05)$, bet silpnesnis už didelio meistriškumo boksininkų ( $p<0,001)$.

5. Visiems respondentams nereikšmingiausias yra karjeros motyvas.

\section{LITERATŪRA}

Coffey, R. E., Cook, C. W., Hunsaker, P. L. (1994). Management and Organizational Behavior. IRWIN.

Csikzentmihalyi, M., Nakamura, J. (1989). The dynamics of intrinsic motaviation. In C. Ames, R. Ames (Eds.). Motivation in Education, Vol. 3: Goals and cognitions (pp. 45-71). New York: Academic Press.

Čepelioniene, J., Ivaškiene, V. (2005). Lietuvos fechtuotojų ir penkiakovininkų sportinès veiklos motyvai. Sporto mokslas, 2 (40), 52-57.

Deci, E. L., Ryan, R. M. (1985). Intrinsic Motivation and Self-determination in Human Behavior. New York: Plenum.

Flood, S., Hellsted, J. (1991). Gender differences in motivation for intercollegiate athletic participation. Journal of Sports Behavior, 3 (14), 159-168.

Herzberg, F. (1996). Work and the Nature of Man. Cleveland: World.

Kinjonen, J. (1991). Personal values and motivation for exercises. Proceedings of the World Congress on Sports for All, 3-7 June.
Malinauskas, R. (2003). Didelio meistriškumo dvikovos sporto šakų sportininkų ir jų rezervo motyvacijos ypatumai. Sporto mokslas, 1 (31), 19-23.

Malinauskas, R. (1998). Vaikinų, kurie renkasi boksą, motyvacijos ypatumai. Sporto mokslas, 3 (12), 20-23.

Sporto terminu žodynas. (2002). Sud. S. Stonkus. T. 1. Kaunas: LKKA.

Wang, J., Biddle, S. (2001). Young people's motivational profiles in physical activity: A cluster analysis. Journal of Sport \& Exercise Psychology, 23, 1-22.

Бондарчук, Т. В., Потапов, В. Н. (2006). Саморегуляция психического состояния спортсменов высшей квалификации. Теория и практика физической культуры, 2, $39-40$.

Худадов, Н. А. (1997). Психолого-педагогические основы спортивной деятельности единобориев высокой квалификации: диссертация канд. психолог. наук. Москва: ГАФК. 


\title{
MOTIVES OF SPORTS ACTIVITIES OF LITHUANIAN BOXERS AND KARATE ATHLETES
}

\author{
Vida Ivaškienė ${ }^{1}$, Virgilijus Vytautas Mačiulis ${ }^{1}$, Leonas Meidus ${ }^{2}$, Vidas Bružas ${ }^{1}$, Vladas Juknevičius ${ }^{3}$ \\ Lithuanian Academy of Physical Education ${ }^{1}$, Kaunas, Vilnius Pedagogical University', Vilnius, \\ Vytautas Magni University ${ }^{3}$, Kaunas, Lithuania
}

\begin{abstract}
The aim of the research was to study and compare the motives of sports activities of Lithuanian boxers and karate athletes.

The methods of the research: 1. The study and analysis of literature sources. 2. Questionnaire survey. 3. Mathematical statistics.

The research using the method of questionnaire survey was carried out during the championship of Lithuania in 2004. The sample consisted of 14 elite boxers and 15 karate performers $(n=29)$ and 16 nonelite boxers and 17 karate performers $(\mathrm{n}=33)$. The total number of subjects was 62 sportsmen $(30$ boxers and 32 karate performers). The sample consisted of athletes in 4 weight categories (from $57 \mathrm{~kg}$ to $75 \mathrm{~kg}$ ). The winners of the first 4 places were attributed to elite sportsmen and those who had taken the last 4 places were attributed to non-elite sportsmen respectively. The average age of the sportsmen studied was $20.5 \pm 2.3$ years.

The research included boxers and karate performers since they distinguish themselves from other representatives of combat sports by fighting in the standing position and blow techniques being used.

The subjects were asked to fill in a standardized F. Herzberg's questionnaire consisting of 56 questions aimed at establishing the following eight motives of activities: financial, recognition and gratitude, responsibility, relations with the leader, career, achievements, nature of activities, and cooperation. Maximum estimation of each motive was set at 28 points.

The data obtained as a result of the research carried out were processed using the methods of mathematical statistics. Student's criterion $t$ was applied in determining difference reliability.

It was found that financial motive was the most important motive of sports activities among elite boxers ( $25.6 \pm 1.02$ points); motives of the nature of the activities ( $23.4 \pm 0.81$ points) and of achievements (23.1 \pm 0.78 points) were also important.

In the case of elite karate performers, the motives of the nature of the activities were the most important (23.5 \pm 0.83 points), motives of cooperation ( $22.3 \pm 0.69$ points $)$ and of achievements $(20.1 \pm 0.65$ points $)$ were important, as well.

The motives of the nature of activities, motives of cooperation and of responsibility prevailed among boxers and karate performers whose mastership was low.

The financial motive of non-elite boxers was stronger than that of karate sportsmen of the same skill level $(\mathrm{p}<0.05)$ but it was weaker than that of elite boxers $(\mathrm{p}<0.001)$.

The comparison of research results obtained from all groups of the athletes studied showed the motive of career being the least important.
\end{abstract}

Keywords: motives of sports activities, high and low mastership, boxing, karate.

Gauta 2005 m. rugsèjo 28 d.

Received on September 28, 2005 